\title{
VERBAL AND NON-VERBAL COMMUNICATION IN TEACHER TALK IN THE CLASSROOM UNIVERSITAS MUSLIM MAROS
}

\author{
Nuraeni $^{1}$, Isnaeni Wahab ${ }^{2}$ \\ 1) ${ }^{2)}$ Universitas Muslim Maros \\ 1) nuraeni@umma.ac.id \\ ${ }^{2)}$ isnaeni@umma.ac.id
}

\begin{abstract}
This research aimed to analyze the forms of verbal and nonverbal communication in teacher talk. The method used in this research was descriptive qualitative. The instrument of the study was the FLINT System and Darn classification. The participants of this research were the teacher and students in a speaking class of the English Department. The results show that teacher talk gives a positive impact on students' performance. During the class interaction, the teacher successfully met the aspects of good teacher talk and applied some forms of FLINT system of verbal communication and some elements of non-verbal communication. For the FLINT system, the teacher applied to ask questions, giving encouragement, giving direction, critiquing students' behavior, dealing with feelings and, prising. For the form of nonverbal communication, the teacher applied only two forms, those are kinesics which is referred to as gestures, and haptics is referred to as touching.
\end{abstract}

Keywords: Teacher Talk, Student Talk, Verbal Communication, Nonverbal Communication.

\section{INTRODUCTION}

Foreign language teaching activity is a complicated process that involves three main factors, those are language learner/learning (How to learn); language/culture (What to Learn); teacher/teaching (How to teach) (Johnson, 2002; Xiao-Yan, 2006). It is important to link the elements to each other to have successful learning. A teacher must understand his students and acknowledge the limits of students' abilities. Before coming to the class, the teachers must prepare a suitable material and method for the development of students' learning.

In Indonesia, English is learned as a foreign language which means many of the learners do not actively use the target language. For most school level students, English is not more than a subject that they have to study once or twice a week with the length is not more than 60 to 90 minutes. Furthermore, few students are interested in 
learning a new language with limited time They believe that learning English is outrageously difficult and not to mention teacher methods that they do not fit in. This reality becomes the cause of why students cannot speak English in their daily life.

However, English as a global language has its charm. Still, many students continue their education to higher education majoring in the English language department. Some of the students, unfortunately, do not have basic at all in learning English. This problem becomes a challenge for English language teachers. One of the ways of handling this problem is to supply effective communication which can gain students' engagement. To achieve this aim, a good teacher talk during class interaction is necessary.

Teacher talk has an important role to ensure the learning process runs well (Cook, 2000) both verbally and non-verbally. In pedagogical theory, it is revealed that the success of classroom verbal and non-verbal talk in the class interaction can be up to $70 \%$ conducted by the teacher since the teacher is the one to pass the knowledge, organize the teaching activity and assist students to be communicative during the class interaction Cook, 2000; Xiao-Yan, 2006). in other words, for language teachers, they are not only acted as "the object of the course" but also as students' medium to reach learning objectives (Xiao-Yan, 2006, pp.6-7).
However, it is the teachers' job to provide opportunities for students to talk to hone their cognitive abilities. Therefore, the teachers need to realize that even though they might the only resource to comprehend a target language, they still need to apply a strategy of an effective way to gain the student talk. Furthermore, Brock (1986) contended that the development of teacher-student talk lies in how teacher talk assists students to participate actively and to improve the language learning effectively.

This study was conducted to explore how teacher's talk verbally and non-verbally gave impacts to students' development in learning a language. This study was carried out to analyze the form of verbal and non-verbal communication during the teaching and learning process. This study was important because it would be able to become a resource for English language teachers to enhance their awareness of carrying out proper teacher talk in the class interaction as well as to help students develop their language ability.

\section{Previous Related Findings}

Sofyan \& Mahmud (2014) did research about teacher talk. The research was implemented in a speaking class. Researchers analyzed their data using Foreign Language Interaction Analysis (FLINT) system. The result said that the teacher used some teacher talk forms. Mostly the teacher used 'asking questions' form, then, followed by 'asking direction'. However, 'giving praises using 
encouragement' was used the least. To balance the teacher-student talk, the teacher formed a pair-group discussion. With their pairs, students started to speak more actively.

Astiti (2012) conducted research to identify the effectiveness/ineffectiveness of teacher talk. The research question is research using observation and questionnaire. three teachers became the objects of the research. For the observation, the data were collected through recording. After that, the data were analyzed qualitatively. The result shows that from the three teachers, they mostly use six footing forms, those are mediator, evaluator, learnings task assignor, teaching material interpreter, inspector, and classroom climate conductor. From the result, it is believed that to have good teacher talk, a teacher must meet the requirement of 3 aspects: interpersonal, pedagogical, and, physical aspects.

Antika \& Ikhsan (2018) carried out a study on nonverbal communication in the teaching and learning process. The objects of the research were two teachers and who taught in secondary education. The data were collected through observation checklists and field notes. The research was based on Schmitz's theory of nonverbal communication (Schmitz, 2012) the result shows that the teachers mostly used kinesics, vocalics, and, proxemics during the teaching and learning process.

\section{The Importance of Teacher Talk}

For decades, Scholars have conducted studies about the importance of teacher talk in teaching a foreign language (Stern, 1983; Nunan, 1991). Nunan contended that Teacher talk for learning a new language is of crucial necessary, not only for organizing the classroom but also for acquisition processes which might the only resource for learner' input to acknowledge the target language (Nunan, 1991; Aghajanzadeh \& Hemmati, 2014), Similarly to Nunan's opinion, Krashen input hypothesis claimed that teacher talk is considered as an important factor for language acquisition which is recognized as an important resource as it is easier to comprehend by the students (Wasi'ah, 2016). It can be implied that the language used in the classroom plays a vital role to teach successfully. Through language, teachers can manage the class to implement the teaching plan whether it leads to success or failure in teaching. From that explanation, it is obvious to say that teachers can act as manager, facilitator, director, and controller (Brown, 2001)

As mentioned previously, teacher talk holds a vital role to enhance students' language ability. In this case, the teachers are required to fully prepare over the material and the method to provide positive milieu and create amiable connection between teacher and student, thus, this situation can raise positive interaction during the learning process (Yafen \& Yuqin, 2010; Putri, 2015). To maximize the teacher 
talk, strategies for interaction are needed by the teacher. Afen \& Yuqin found in their research that repetition, Prompting, prodding, and, expansions are effective strategies to create an interactive class. In addition, effective teacher talk comes from the quality of the teachers themselves. Stern (1983) in his article implied that an effective teacher is the one who meets the instructional component, those are language background, teaching experience and, formulated theoretical presuppositions about language learning and teaching.

\section{Verbal and Non-verbal Communication}

Verbal communication in teacher talk is simply the interaction between teachers and students to gain mutual understanding which is expressed through oral communication. Verbal communication is a skill to reveal ideas verbally using words either written or spoken in a logical way which is easily understood by students (Wahyuni, 2018). During the interaction, effective verbal communication counts on mutual performance between the teacher and the students as a result of vocal and visible behavior. When teachers use verbal communication, total interactive performance is required which cannot be separated toward non-verbal communication such as how they to position their body, use various gestures, focusing their seeing, sometimes using hand movement politely (Jones, \& LeBaron, 2002).

In terms of verbal communication in teacher talk, the teacher uses some categories to deal with effective teacher talk in foreign- language interaction which is called FLINT system. Those are dealing with feelings, praising and encourages, using student's ideas, asking questions, giving information, giving directions, and critiquing students' behavior (Brown, 2007).

Contrarily, non-verbal communication in teacher talk refers to talk without words in which the teachers use sign from their body for affirming the verbal communication by using expressions, gestures, actions during interaction (Sutiyatno, 2018). These signs serve as supports for the teachers. As Negi (2009) in her article claimed that non-verbal communication has an important part in a class interaction as a form of motivation to trigger students to be more active.

Throughout the communication, the emergence of non-verbal communication is inevitable. Different elements of non-verbal communication are employed depending on the situation in the class. It ranges from body movements to postures (Mainez, 2017). Darn (2005 cited from Elfatihi, 2006) classified the non-verbal communication into some forms: Kinesics or body movements or gestures, proxemics or space management in term of the social and physical environment, haptics or using touch, Oculesics or using eye contact, vocalics refers to tone, pitch, timbre, volume and speed of the voice, facial expression or the gesture of the face's muscles, posture refers to the position and orientation of the body, Olfactics or using smell, silence or the absence 
of linguistic words of forms, adornment refers to clothes, jewelry and hairstyle and, chronemics or time management.

\section{Research Question}

What are the forms of verbal and nonverbal communication used in the teacher talk?

\section{Objectives of the Research}

This research aimed to find out the forms of verbal and nonverbal communication in teacher talk.

\section{METHODS}

This research was qualitative in which the data were the utterances containing verbal and nonverbal communication of teacher talk which was uttered by participants. Then a transcription of the utterances was made as data. The participant of this research was an English teacher and the students in speaking class. The data was gathered through observation by recording the teaching and learning class of the participants. The data were recorded in the form of video material with a capacity of $313.675 \mathrm{~kb}$ as an mp4 file. The data were then transcribed to analyze it.

\section{FINDINGS AND DISCUSSION}

FINDING

Based on the data analysis, the findings showed that the participant did verbal and nonverbal communication during her teaching class which will be elaborated further.

\section{Verbal Communication}

\section{a) Asking Questions}

The participant began the lesson by flooring a question. She did this to engage students toward her material. The following extract is one of a good way to start teaching:

\section{Extract 1}

Teacher : (while writing on the board) Okay, could you list some expressions. coba sebutkan....could you list some expressions when you..when you feel surprised...when you're surprised by something

Student 1 : Ohh...my God .. !!

Teacher : ok, ok, mention one

Student 2 : What..???

Teacher : What...ok

\section{b) Encourages}

The participant then tried to gain more responses by encouraging the other students to be part of the conversation.

\section{Extract 2}

Teacher: could you mention one? lask one of the students)

Student1 : wow. !!!

Teacher : Wow, wow, ok so you may say wow... (while writing on the board)

Student2 : amazing !

Teacher : amazing what else

Student3 : are you sure?

Teacher : are you sure? 
c) Giving direction

To engage students to speak actively, the participant gave direction which students can understand

\section{Extract 3}

Teacher : ok, now I want you to think...silahkan berfikir...I want you to think...I want you to...think..ee..one case..that can make your friend surprise... you can surprise your friend who sits next to you. ..silahkan. example.. (walking toward students)

\section{Extract 4}

Teacher: ok, I want you to think one case ya.. one case and make your friend surprise.

Ok, 3 minutes to think, 3 menit untuk berfikir sekarang, I want you to think one case that can surprise your friend 3 menit dari sekarang, don't ask your friend yaaa, don't tell your friend.... don't tell your friend that surprising thing.

From the extract, it can be seen that the participant wanted to teach them about Surprise expression, and she began by asking the students about surprise expression that they knew. Here she was successful to make the students thinking about the expression, After encouraging students to be more active, some students told some expression that they usually used in their daily activity, and after making the list, She directed the students to think something that could make their friend surprised. It made them curious to try to make something that could surprise their friend.

d) Critiquing Students' behavior

One of the students was not paying attention, therefore the participant tried to correct his behavior

\section{Abstract 5 :}

Teacher :Hello, please listen to what I will say...

(touch his arm) Bill, be patient because your lovely dog got an accident

Students : hahaha (laughing)

Student1 : oh my God.......

Teacher : your lovely dog...You must be patient because your lovely dog got an accident...you know. e

....there is..there is a motor crushed

Student1 : Oh, My God ??!!

Because that was a speaking class, the class was so noisy and the participant tried to calm down them by saying "Hello, Please listen what I will say ", she tried to gain the students' attention because she wanted to make an example so all the class would understand what they would do. She gave a fake example but it gained full attention from her students. "(touch his arm) Bill, be patient because your lovely dog got an accident", here the students knew that 
Bill didn't have a lovely dog, but Bill can make a very good expression by saying "Oh My God".

After giving the students a simple example, she asked the students to make a case that could make their friend surprise just like she did, and she made limited time to maximize the time. By giving them limited time, students could be more focused.

\section{e) Dealing with feeling}

When students were about to practice the lesson, the participant picked a student who wanted to practice first. She did that because one of the students was fully motivated to learn and she did not want to let her down

\section{Extract 6 :}

Teacher : Ok. I will start from...

Student : Widia .....

Teacher: widia, ok Widia..you first..could you come forward..?

Ya.. ask your friend silahkan [please] pilih teman kamu. Choose one of your friend... yang ingin di buat kaget [the one that you want to surprise].

When the students had already prepared the case, she directed the students to practice in front of the class by choosing someone who wanted to practice first, when she said "Ok. I will start from ", and one of the students said "Widia" and she said "ok, widia", she tried not to disappoint her students and picked her student's choice. When Widia was ready to present her case, she asked " could you come forward?". As a teacher, she tried to be polite in front of the students because the teacher is a model in front of the students so she tried to be nice and polite.

f) Praise

During the teacher talk, praise is really important as it is the way to show appreciation of students' work. Unfortunately, in this teaching activity, the participants praised the student only once which will be shown in the extract bellow

\section{Extract 7}

(students practiced a surprise expression)

Student1 : You are not my girlfriend [anymore] Inci

Student2 : are you kidding me ...!!!

Teacher : Ok, nice, thank you

After students create a very small conversation, the teacher felt satisfied and she gave a compliment by saying $\mathbf{O k}$, nice, thank you.

\section{Non-Verbal Communication}

There are many forms of non-verbal communication those are; Physical Appearance, Territory and Personal Space (Proxemics), Facial Expressions, Gestures \& Posture, Touch (Tactile Communication), Eye Contact, Vocal Cues that Accompany Speech (Paralanguage), Time (Chronemics).

During the learning process, when a teacher instructed the students, it cannot be denied that non-verbal communication can 
emerge, and sometimes non-verbal communication is more understood by the students than verbal communication. From the data, it is found that there were several nonverbal communications done by the participants during her teaching time and it can be seen on the extract bellow

\section{Extract 1 ;}

Students : Ohh..my God..!!

Teacher : ok, ok, mention one

Students : What..????

Teacher : could you mention one? (she goes forward to the students while points to the student with palm open) ( touch a student's book)

Students : wow. !!!

Teacher : Wow, wow, ok so you may say 'wow' ...

There was two non-verbal communication that happened, The first was Kinesics, that was a gesture and the second was Haptics, which was a touch. When the participant asked one of the students while walking forward toward that student, she pointed to the student by using his palm open. That was the sign that the teacher asked her student politely, sometimes we use our point finger to point students and it is not very polite. When she stood next to the student who opened the book she touched the book and that was the sign that the student had to close the book.

\section{Extract 2 :}

Students : wow...!!!! (two students who came late entered the room)

Teacher : wow....(smiling while clapping her hand unsoundly)..what a nice couple....wow,

Teacher : Hello, please listen to what I will say...

Teacher : (touching her arms) Bill, be patient because your lovely dog got an accident

Students : hahaha (laughing)

Student 1 : oh my God

Teacher : your lovely dog...anjing kesayanganmu. You must be patient because your lovely dog got an accident...you know. e ....there is..there is a motor crushed

Student 1 : oh My God ??!!

Two nonverbal communication emerged in this conversation. The first was Kinesics, that was a gesture and the second was Haptics, which was a touch. At first when she wanted to make an example and suddenly two students who came late entered the class without warning so some of the students expressed her by yelling "WOW..!!!" and participants also said "Wow" while clapping her hand. The sign that it was an example of expression.

When she made an example and she said, "Bill, be patient because your lovely dog got an accident" while touching Bill's arm. She used non-verbal communication of Haptic, 
which was the use of touch. When she touched his arm she meant to make him calm down because his lovely dog got an accident.

\section{Extract 3 :}

Teacher: ok, I want you to think one case ya.. one case and make your friend surprise...

Ok, 3 minutes to think (while her three fingers on the air), 3 menit untuk berfikir sekarang, I want you to think one case that can surprise your friend 3 menit dari sekarang,

Here She used Kinesics non-verbal communication, that was a gesture. She wanted to make sure that all the students will finish the task she gave in three minutes.

\section{DISCUSSION}

After analyzing the data, it is found that effective verbal communication happened in the class as well as some of the non-verbal communication during the teaching process resulting in a positive effect on students' performance. Johnson contended that to be referred to as effective communication, teacher talk needs to meet the requirement of three major aspects: 'Physiological aspect' which is referred to the ability to maintain voice during the activity interaction. 'Interpersonal aspect' means the ability to control the class. 'Pedagogical aspect' which means the ability to organize the lesson to gain effective interaction (Sukarni \& Ulfah, 2015).
As it is a speaking class, the class was very attractive. From the' psychological aspect', the teacher met the criteria by having a good and clear voice to utter ever instruction. Her clear voice could cover all students' attention from the beginning until the end of the class. Moreover, from the 'interpersonal aspect', the teacher was able to organize the lesson by structuring it. It began with a question as a trigger to students' curiosity. It was then followed by an explanation and ended up with practice by using a small talk method. Furthermore, the 'pedagogical aspect' was met by being able to control the class by criticizing the behavior politely. This finding is in line with research carried out by Astiti (2012) who found that the three major aspects of teacher talk were considered as strong and affective aspects of teacher talk that can influence students' performance positively.

During the class interaction, some forms of elements of verbal communication were used those are dealing with feelings, praising and encourages, asking questions, giving directions, and critiquing students' behavior (Brown, 2007). from those elements, asking questions encourages and, giving directions were used the most. While praising was used the least. This research is in agreement with a study conducted by Sofyan \& Mahmud (2014) who claimed that during the class interaction, asking questions and using direction dominated the teacher talk while praising and encouragement did they the least. 
For non-verbal communication, two nonverbal components that happened in the class during the teaching process are Kinesics and Haptics. This finding is compatible with a study conducted by Antika \& Ikhsan (2018). in their finding, the teacher used some signs of nonverbal communication and, these two types of nonverbal communication were the most frequently used in the class interaction.

In this research, kinesic happened when she asked one student to mention one of surprising expression, she used her hand with palm open to do a polite gesture, and the second it happened when two students who came late and she smile while clapping her hand unsoundly and said Wow..., as a sample of surprising expression, and the third when she asked the students to make a case within three minutes while her three fingers on the air, here she wanted to make them sure that they would finish the task after three minutes.

Meanwhile, Haptic happened twice, first when she touched a student's book, that meant that she wanted the student close her book and the second when she made a case example, she touched bill's arm and said: "Bill, be patient because your lovely dog got an accident". From the expression, she wanted to make Bill calm down due to the accident.

\section{CONCLUSION}

From the findings and analysis, it could be figured out that positive teacher talk happened because the teacher can structure her voice, her talk, and her lesson. As a result, students were active and able to gain knowledge from the teacher. In terms of verbal communication, the teacher used some elements of verbal communication such as asking questions, using directions, using praise. However, she used the praise the least. That would be better if she kept praising her students who are active which can be the source of motivation to be better in learning.

For non-verbal communication, only two forms happened in the class during the teaching process, those are Kinesics and Haptics, and the other such as Proxemics, Oculesics, Olfactics did not happen in the class. Kind of kinesics was a gesture by using hand and kind of haptic was touching by using hand.

Hopefully, this research would give another contribution in understanding verbal and non-verbal communication that will happen in the class during the teaching process. It is also expected that this research would be useful for further research concerning verbal and non-verbal communication in teacher talk.

\section{REFERENCES}

Aghajanzadeh Kiasi, M., \& Hemmati, F. (2014). The importance of 'teacher talking teaching EFL writing, Portal Linguarium, Payame Noor University, Iran., 95-108

Antika, R., \& Ikhsan, M. K. (2018). Teachers' Nonverbal Communication in English Teaching and Learning Process. TELL-US Journal, 4(1), 65-79.

Astiti, N. W. W. (2012). An Analysis of Teacher Talk in English Classes in SMK PGRI 4 
Denpasar. Jurnal Pendidikan dan Pembelajaran Bahasa Indonesia, 1(2).

Brown, H. Douglas. (2001). Teaching by Principles: An Interactive Approach to Language Pedagogy, Second Edition. San Francisco: Longman.

Brown, H. Douglas (2007). Teaching by Principles. San Francisco State University. United State of America: Pearson Longman.

Elfatihi, M. (2006). The Role of Nonverbal Communication in Beginners' EFL Classrooms: Sale Junior High Schools as a Case. Online Submission.

Johnson Keith. (2002). An Introduction to Foreign Language Learning and Teaching. Beijing: Foreign Language Teaching and Research.

Jones, S. E., \& LeBaron, C. D. (2002). Research on the relationship between verbal and nonverbal communication: Emerging integrations. Journal of Communication, 52(3), 499-521.

Mainez Prado, I. (2017). Nonverbal communication in English as a second language.

Nunan, D. (1991). Language Teaching Methodology: A Textbook for Teachers.Cambridge: Cambridge University Press.

Putri, D. S. (2015). The Analysis of Teacher Talk and The Characteristic of Classroom Interaction in English as A Foreign Language Classroom. Journal of English and Education, 3(2), 16-27.

Schmitz, Andy. 2012. A Primer a Communication Studies. http://2012.books.lardbuckketorg.
Sofyan, R. R., \& Mahmud, M. (2014). Teacher talk in classroom interaction: A study at an English department in Indonesia. ELT WORLDWIDE, 1(1), 45-58.

Stern, H. H. (1983). Fundamental Concepts of Language Teaching. Shanghai: Shanghai Foreign Language Education Press.

Sukarni, S., \& Ulfah, S. (2015). An Analysis of Teacher and Student Talk in the Classroom Interaction of the Eighth Grade of SMP Negeri 18

Purworejo. Vision: Journal for Language and Foreign Language Learning, 4(2), 261-277.

Sutiyatno, S. (2018). The effect of the teacher's verbal communication and non-verbal communication on students' English achievement. Journal of Language Teaching and Research, 9(2), 430-437.

Wahyuni, A. (2018,). The power of verbal and nonverbal communication in learning. In the 1st International Conference on Intellectuals' Global Responsibility (ICIGR 2017). Atlantis Press.

Wasi'ah, N. (2016). A study of teacher talk in classroom interaction at an Islamic Senior High School. OKARA: Jurnal Bahasa dan Sastra, 10(1), 29-43.

Xiao-Yan, M. A. (2006). Teacher talk and EFL in university classrooms. Unpublished master's thesis, Chongqing Normal University \& Yangtze Normal University, China, 5-13.

Yanfen, Liu., and Yuqin, Zhao. (2010). A Study of Teacher Talk in Interactions in English classes. Chinese Journal of Applied Linguistics, 33(2), 76-86. 